\title{
Effect of active immunization against recombinant-derived chicken prolactin fusion protein on the onset of broodiness and photoinduced egg laying in bantam hens
}

\author{
J. B. March, P. J. Sharp*, P. W. Wilson and H. M. Sang \\ Division of Development and Reproduction, Roslin Institute (Edinburgh), Roslin, Midlothian EH25 9PS, \\ UK
}

\begin{abstract}
The hypothesis that the onset of incubation behaviour (broodiness) in the domestic hen is induced by an increase in prolactin secretion was investigated by actively immunizing bantam hens against recombinant-derived chicken prolactin. A second objective was to establish whether active immunization against prolactin affects photoinduced onset of egg laying and the rate of egg production. The immunogen was a fusion protein ( $\mathrm{ggal}_{\mathrm{s}}-$ prolactin, $23 \mathrm{kDa}$ ) produced in Escherichia coli, comprising chicken prolactin (without the nine amino-terminal amino acids) fused to 18 amino acids of $E$. coli $\beta$-galactosidase. A control immunogen was produced in the same strain of $E$. coli harbouring the same plasmid vector used to produce $\beta \mathrm{gal}_{\mathrm{s}}$-prolactin minus the prolactin gene sequence. Hens were immunized i.m. with $1 \mathrm{mg}$ of protein containing $0.8-0.9 \mathrm{mg}$ of fusion protein in Freund's incomplete adjuvant at $4-8$ week intervals beginning before or after egg laying, which was induced by increasing the daily photoperiod. The $\beta$ gal -prolactin immunogen, but not the control immunogen, stimulated the production of antibodies to chicken prolactin. In Expts 1,2 and 3, hens were placed in floor pens with nest boxes after photostimulation to induce broodiness. In these experiments, immunization with $\beta \mathrm{gal}_{\mathrm{s}}$-prolactin reduced the incidence or delayed the development of broodiness. This effect was more pronounced if immunization was initiated before, rather than after, the onset of egg laying. In Expts 1 and 2 hens

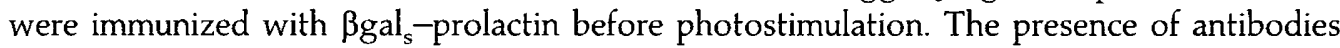
to prolactin in their blood did not affect photoinduced onset of egg laying. In Expt 4, hens were maintained in individual cages to suppress the development of broodiness to measure the rate of egg laying. In these conditions, hens immunized with $\mathrm{Bgal}_{\mathrm{s}}$-prolactin laid eggs at the same rate as did control hens. It is concluded that in the domestic hen increased prolactin secretion plays an important role in the initiation of incubation behaviour, and that active immunization against prolactin does not affect photoinduced onset or subsequent rate of egg laying.
\end{abstract}

\section{Introduction}

It has been suggested that the onset of incubation behaviour in chickens and turkeys is initiated by an increase in prolactin secretion (for reviews see Lea, 1987; El Halawani et al., 1988; Sharp. 1989). Support for this view comes from the observations that the onset of incubation in the bantam hen is correlated with an increase in plasma prolactin concentration (Sharp et al., 1979, 1988; Lea et al., 1981) and that established incubation behaviour is rapidly terminated after passive immunization with an antibody against the chicken prolactinreleasing hormone, vasoactive intestinal polypeptide (Sharp et al., 1989). More direct evidence comes from the demonstration

*Reprint requests.

Revised manuscript received 28 October 1993. that incubation behaviour can be induced in turkeys by systemic or intracranial administration of ovine prolactin (El Halawani et al., 1986; Youngren et al., 1991). However, administration of ovine prolactin to laying chickens fails to induce incubation behaviour although it does inhibit egg laying (Open and Proudman, 1980). The reason for these inconsistent observations is uncertain.

The current study was undertaken to demonstrate a role for prolactin in the initiation of incubation behaviour in bantam hens using a novel experimental approach involving active immunization against chicken prolactin. A second objective was to establish whether active immunization against prolactin affects photoinduced onset of egg laying and the rate of egg production. The immunogen was a recombinantderived fusion protein consisting of $95 \%$ of the amino acid

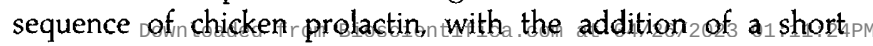


amino acid sequence from a bacterial enzyme to enhance immunogenicity.

\section{Materials and Methods}

\section{Hens}

Bantam hens were obtained from the breeding flock of the Roslin Institute, Edinburgh, and reared in cages under a photoperiod of $14 \mathrm{~h}$ light:10 h dark. At 18 weeks of age birds were caged individually and the daily photoperiod reduced to $8 \mathrm{~h}$ light:16 h dark to prevent onset of egg laying. The onset of egg laying was stimulated by increasing the photoperiod to $14 \mathrm{~h}$ light: $10 \mathrm{~h}$ dark. Hens were fed layers mash (Roslin Institute) ad libitum and daily records were kept of egg production. Broodiness was induced by transferring groups of five hens maintained on a $14 \mathrm{~h}$ light: $10 \mathrm{~h}$ dark photoperiod to floor pens $(4 \mathrm{~m} \times 2 \mathrm{~m})$ containing five nest boxes with eggs. Birds held in floor pens were inspected twice a day for evidence of broodiness over a period of several weeks until $80 \%$ of the control birds had become broody. Broodiness was recognized as persistent nesting combined with characteristic clucking.

\section{Reagents, plasmids and bacterial strain}

Unless otherwise stated, reagents were obtained from FSA (Loughborough). Restriction enzymes were purchased from Boehringer-Mannheim (Lewes), and T4 DNA ligase and Klenow polymerase were obtained from Northumbria Biologicals Ltd (Cramlington). For the construction of the radiolabelled probe, $\left[\alpha_{-}^{32} \mathrm{P}\right] \mathrm{dCTP}\left(3000 \mathrm{Ci} \mathrm{mmol}{ }^{-1}\right)$ was obtained from Amersham International (Amersham). The synthetic oligonucleotide linker was obtained ready phosphorylated from Boehringer-Mannheim.

The general-purpose cloning vector pUC19 (Yanish-Perron et al., 1985), encoding the $\alpha$ fragment of Escherichia coli $\beta$-galactosidase under the control of the inducible lac promoter, was used to construct a recombinant plasmid. Expression of the fusion gene was induced by addition of isopropyl- $\beta$ - $D$ thiogalactopyranoside (Novabiochem, Nottingham) to the growth medium.

The host strain used for transformation of the recombinant plasmid and subsequent production of recombinant fusion protein was $E$. coli K-12 BMH71-18 (Alac-pro, $F^{\prime}$ lac12 $2^{q}$ lacZ $\triangle M 15$, supE) (Messing et al., 1977). E. coli cells were grown at $37^{\circ} \mathrm{C}$ in Luria-Bertani medium (Sambrook et al., 1989) supplemented with $100 \mu \mathrm{g}$ ampicillin $\mathrm{ml}^{-1}$ when appropriate. Transformations were carried out according to the protocol of Hanahan (1983).

\section{Construction of the recombinant plasmid, $p \beta g a l_{S}$-prolactin}

General cloning procedures were carried out as described by Sambrook et al. (1989). A 0.74 kilobase-pair (kb) blunt-ended HincII complementary DNA fragment (cDNA) encoding all but the first nine amino acids of mature chicken prolactin (Hanks et al., 1989) was ligated to a synthetic oligonucleotide linker $\left(5^{\prime}\right.$-GGGATCCC-3') to allow an in-frame gene fusion to be made. The resulting fragment was cloned into PUC19 vector DNA cut with BamHI, and transformed into E. coli. This construct was predicted to result in the production of a fusion protein $\left(\beta_{\mathrm{gal}} \mathrm{s}\right.$-prolactin) containing the first 18 amino acids of the amino terminus of $\beta$-galactosidase, encoded by the lac $Z$ gene of the vector, fused to all but the first nine amino acids of chicken prolactin. The $\mathrm{Bgal}_{\mathrm{S}}$-prolactin fusion protein was predicted to have a molecular mass of about $23 \mathrm{kDa}$.

After transformation into $E$. coli, recombinant plasmids were identified by their ability to hybridize with the $0.74 \mathrm{~kb}$ blunt-ended Hincll chicken prolactin cDNA fragment; this probe had been radiolabelled using $\left[\alpha^{32} \mathrm{P}\right] \mathrm{dCTP}$ as described by Feinberg and Vogelstein (1984).

\section{Expression and extraction of $\beta_{g a l_{s}}$-prolactin}

Cultures of BMH71-18 cells carrying $\mathrm{p} \beta \mathrm{Bgal}_{\mathrm{S}}-$ prolactin grown overnight in L-broth (Sambrook et al., 1989) plus $100 \mu \mathrm{g}$ ampicillin $\mathrm{ml}^{-1}$ were diluted 1:100 into $1 \mathrm{l}$ of fresh medium and grown with vigorous shaking at $37^{\circ} \mathrm{C}$ until an absorbance at $540 \mathrm{~nm}$ of 0.5 was reached. Isopropyl- $\beta$ - $D$-thiogalactopyranoside was then added to a final concentration of $20 \mathrm{ng} \mathrm{ml}^{-1}$ and the cultures grown for a further $2 \mathrm{~h}$ with vigorous shaking at $37^{\circ} \mathrm{C}$. Cells were harvested by centrifugation ( $100 \mathrm{~g}$ for $5 \mathrm{~min}$ ) and washed in $100 \mathrm{ml} \mathrm{TE}$

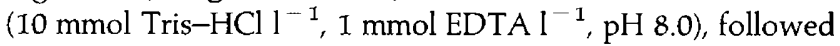
by centrifugation ( $100 \mathrm{~g}$ for $5 \mathrm{~min}$ ) and resuspension in $20 \mathrm{ml}$ of buffer [10 mmol Tris- $\mathrm{HCl}^{-1}, \mathrm{pH} 8.0,10 \mathrm{mmol} \mathrm{MgCl} \mathrm{l}^{-1}$, $10 \mathrm{mmol} \beta$-mercaptoethanol $1^{-1}$ (Sigma Chemical Co, St Louis, $\mathrm{MO})]$. Lysozyme (20 mg, Sigma Chemical $\mathrm{Co}$ ) was added; the mixture was left for $15 \mathrm{~min}$ at $37^{\circ} \mathrm{C}$, transferred to ice, and the cells lysed using a Heat Systems Ultrasonics W385 Sonicator (Life Science Laboratories, Luton). Unlysed cells and large debris were removed by centrifugation at $1000 \mathrm{~g}$ for $5 \mathrm{~min}$ at $4^{\circ} \mathrm{C}$. Fusion proteins were recovered as inclusion bodies from the supernatant by centrifugation at $15000 \mathrm{~g}$ for $15 \mathrm{~min}$ at $4^{\circ} \mathrm{C}$. The pellet was resuspended in $15 \mathrm{ml}$ of $6 \mathrm{~mol}$ urea $\mathrm{I}^{-1}$ containing $0.1 \mathrm{~mol} \beta$-mercaptoethanol $1^{-1}$ and $0.05 \%$ SDS. Insoluble matter was removed by centrifugation at $15000 \mathrm{~g}$ for $30 \mathrm{~min}$ at $4^{\circ} \mathrm{C}$, followed by dialysis of the supernatant against three changes of distilled water overnight. The mixture was cleared of precipitated matter by centrifugation at $15000 \mathrm{~g}$ for $15 \mathrm{~min}$ at $4^{\circ} \mathrm{C}$. The supernatant was stored at $-20^{\circ} \mathrm{C}$.

Proteins in total E. coli homogenates and in the final supernatant were analysed by SDS-PAGE (Phastsystem, Pharmacia, Milton Keynes) to estimate the yield of fusion protein and total protein content. The SDS-PAGE gels were subjected to western analysis (Towbin et al., 1979) using the chicken prolactin antibody described by Hanks et al. (1989) to confirm the production and size of $\mathrm{Bgal}_{\mathrm{S}}$-prolactin. The SDS-PAGE gels were stained with Coomassie blue and scanned using a Shimadzu CS900 scanner (V. A. Howe Ltd, London) to estimate the amount of protein in each band. This information was used to calculate the yield of recombinant-derived fusion protein.

Extracts of cultures of E. coli K-12 BMH71-18 harbouring the cloning vector $\mathrm{PUC19}$ without the chicken prolactin gene were produced in the same manner to provide the control immunogen. 


\section{Experimental design}

Each bird was immunized with $1 \mathrm{mg}$ of protein containing $0.8-0.9 \mathrm{mg}$ of fusion protein. The protein was dissolved in physiological saline and emulsified 1:1 in incomplete Freund's adjuvant (Sigma). The emulsion was subsequently dispersed into an equal volume of physiological saline solution containing $0.2 \%$ Tween 80 . Birds were immunized using $1-2 \mathrm{ml}$ of emulsion injected into two sites in both the right and left breast muscles at intervals of 4-8 weeks. Blood samples $(1 \mathrm{ml})$ were collected every week or every 2 weeks by direct venepuncture from a wing vein, and the plasma was stored at $-20^{\circ} \mathrm{C}$ until assayed for chicken prolactin antibodies. Four experiments were carried out.

Experiment 1. The purpose of the first experiment was to establish whether active immunization against prolactin inhibits the induction of egg laying by photostimulation. Twentyweek-old photosensitive, non-laying hens caged individually and exposed to short days ( $8 \mathrm{~h}$ light:16 $\mathrm{h}$ darkness) were immunized with $\mathrm{Bgal}_{\mathrm{S}}$-prolactin $(n=18)$ or with control immunogen $(n=16)$ on two occasions separated by 28 days. At the time of the second immunization the hens were photostimulated ( $14 \mathrm{~h}$ light: $10 \mathrm{~h}$ darkness) to induce egg laying. After a further 28 days the birds were transferred to floor pens to induce broodiness.

Experiment 2. The second experiment was carried out after the first experiment demonstrated that active immunization against prolactin does not prevent photoinduced egg laying. The purpose of the second experiment was to establish whether maintenance of prolactin antibody titres after the onset of egg laying and transfer to floor pens would inhibit the development of broodiness. Twenty-one-week-old photosensitive, individually caged hens, held on short days, were immunized with $\beta g a l_{s}$-prolactin $(n=10)$ or with control immunogen $(n=10)$ on two occasions separated by 49 days. At the time of the second immunization, the hens were exposed to long days (14 h light:10 $\mathrm{h}$ darkness) to induce egg laying. After a further 35 days, when all the hens were laying, they were immunized again and transferred to floor pens to induce broodiness. The experiment was extended to demonstrate that hens actively immunized against prolactin failed to become broody because of high blood titres of prolactin antibody rather than an inability to respond to environmental signals that induce broodiness.

After all the hens had been in floor pens for 49 days, which should have been sufficient for broodiness to develop, they were transferred to individual cages for 56 days to allow prolactin antibody titres to decrease. All hens were then transferred back to floor pens to induce a second round of broodiness.

Experiment 3. The purpose of the third experiment was to establish whether active immunization of photostimulated laying hens against prolactin inhibits the development of broodiness. Twenty-eight-week-old laying hens that had been photostimulated for 6 weeks and had been laying for
3-4 weeks were immunized with $\beta \mathrm{gal}_{\mathrm{s}}-$ prolactin $(n=21)$ or with control immunogen $(n=21)$ and transferred to floor pens to induce broodiness. High titres of prolactin antibodies were maintained by immunizing the hens again 42 days later, and after $80 \%$ of the control birds had become broody all birds were returned to cages for 28 days to break broodiness and stimulate egg laying. The birds were then immunized again and transferred to floor pens to induce a second round of broodiness. An attempt was made to maintain high titres of prolactin antibodies by immunizing the hens again 42 days after being transferred to floor pens for the second time.

Experiment 4. The purpose of the fourth experiment was to establish whether active immunization against prolactin effects the persistency of egg laying in the absence of environmental stimuli provided by floor pens and nest boxes to induce broodiness. Twenty-week-old photosensitive, non-laying hens caged individually and exposed to short days were immunized with $\mathrm{Bgal}_{S}-$ prolactin $(n=22)$ or with control immunogen $(n=24)$ on two occasions separated by 42 days. When the hens were immunized for the second time, the photoperiod was increased to $14 \mathrm{~h}$ light:10 $\mathrm{h}$ dark to stimulate egg laying. They were re-immunized on two further occasions, 42 and 70 days after exposure to long days.

\section{Measurement of chicken prolactin antibodies}

Plasma was assayed for the presence of chicken prolactin antibodies using a modified enzyme-linked immunosorbent (ELISA) protocol. Recombinant chicken prolactin (50 ng; Hanks et al., 1989) in $50 \mu \mathrm{l}$ water was added to each well in 96-well microtitre plates and allowed to dry overnight. Each well was then filled with $200 \mu \mathrm{l}$ block solution and the plates were left for a minimum of $2 \mathrm{~h}$. The block solution, required to eliminate nonspecific binding, was made by adding $5 \mathrm{~g}$ dried skimmed milk powder to $100 \mathrm{ml}$ TBST $\left(5.0 \mathrm{mmol}\right.$ Tris- $\mathrm{HCl} \mathrm{l}^{-1}, \mathrm{pH} \mathrm{7.5}$, $200 \mathrm{mmol} \mathrm{NaCl} \mathrm{I}{ }^{-1}, 0.05 \%$ (v/v) Tween 20). Wells were aspirated and $100 \mu \mathrm{l}$ chicken plasma samples, diluted 1:1000, were added. These were left for $2 \mathrm{~h}$ at room temperature. Plates were then washed five times in TBST, followed by the addition of $100 \mu \mathrm{l}$ rabbit anti-chicken $\operatorname{lgG}$ conjugated to horseradish peroxidase (Sigma Chemical Co), diluted 1:2000, in block solution. Plates were left for $2 \mathrm{~h}$ at room temperature, washed ten times in TBST, and then assayed for peroxidase activity using $o$-phenylenediamine (Sigma Chemical $\mathrm{Co}$ ) as a substrate. Plates were read using a Dynatech MR700 Multiplate Reader (Dynatech, Billinghurst) at a wavelength of $490 \mathrm{~nm}$ (test filter 4).

\section{Statistical analyses}

Statistical analyses were carried out by standard analyses of variance or Student's $t$ test as appropriate. The Fisher exact probability test was used for a comparison of the number of birds displaying incubation behaviour in each treatment group. 
(a)

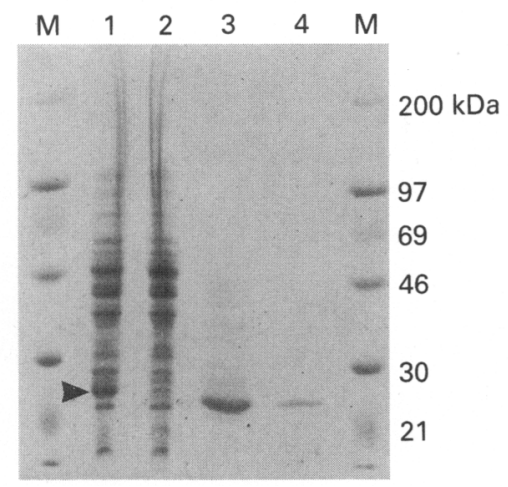

(b)

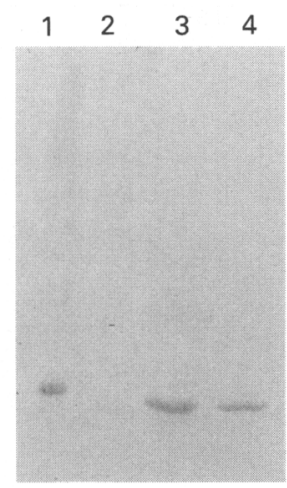

Fig. 1. An analysis of the stages of purification of the chicken prolactin fusion protein ( $\beta \mathrm{gal}_{\mathrm{S}}$-prolactin) extracted from Escherichia coli K-12 BMH71-18 containing a plasmid (pUC19) encoding the amino acid sequence of the protein on (a) an SDS-PAGE gel stained with Coomassie blue and (b) a western blot of the same gel using an antibody to chicken prolactin. Labeiled lanes are: $M$, molecular size markers with sizes shown; 1, total proteins; 2, control proteins extracted from $E$. coli containing the same plasmid-encoding vector without the prolactin gene sequence; 3 , protein extracted from inclusion bodies; and 4 , chicken prolactin. The arrowhead shows the position of $\beta_{g a l}-$ prolactin in lane 1 .

\section{Results}

\section{Yield and characterization of $\beta g a l_{S}$-prolactin}

After induction of expression, extracts of proteins from inclusion bodies found in $E$. coli K-12 BMH7I-18 containing the plasmid $\mathrm{p} \beta \mathrm{Bal}_{\mathrm{S}}$-prolactin yielded a fusion protein with a molecular mass of $23 \mathrm{kDa}$ (Fig. Ia). This protein bound to a chicken prolactin antibody on a western blot (Fig. $1 \mathrm{~b}$ ). The $23 \mathrm{kDa}$ fusion protein represented $10 \%$ of the total protein in the crude E. coli extract and $80-90 \%$ of the protein in the inclusion bodies (data not shown). No binding of chicken prolactin antibody was detected in the control extract of $E$. coli K-12 BMH71-18 harbouring the pUC19 vector only. The size of the fusion protein corresponded to that predicted from the nucleotide sequence of the transgene cloned into the pUC19 vector. The $\beta_{g a l}-$ prolactin protein was found to have a similar molecular size to native chicken prolactin $(22 \mathrm{kDa})$ by western blotting analysis (Fig. Ia, b).

\section{Effect of active immunization with $\beta g a l_{s}$-prolactin on photoinduced onset of egg laying}

Active immunization of photosensitive non-laying hens with $\mathrm{Bgal}_{S}$-prolactin stimulated the production of prolactin antibodies (Fig. 2a), the titres of which were at their highest when the birds were transferred from short to long days to stimulate egg laying (Fig. 2a). Immunization with the control immunogen did not stimulate prolactin antibody production. Egg laying was induced after photostimulation in all the hens, with the first eggs being laid $20 \pm 4$ and $18 \pm 3$ days (not significantly different) after transfer to long days in the experimental and control birds, respectively.
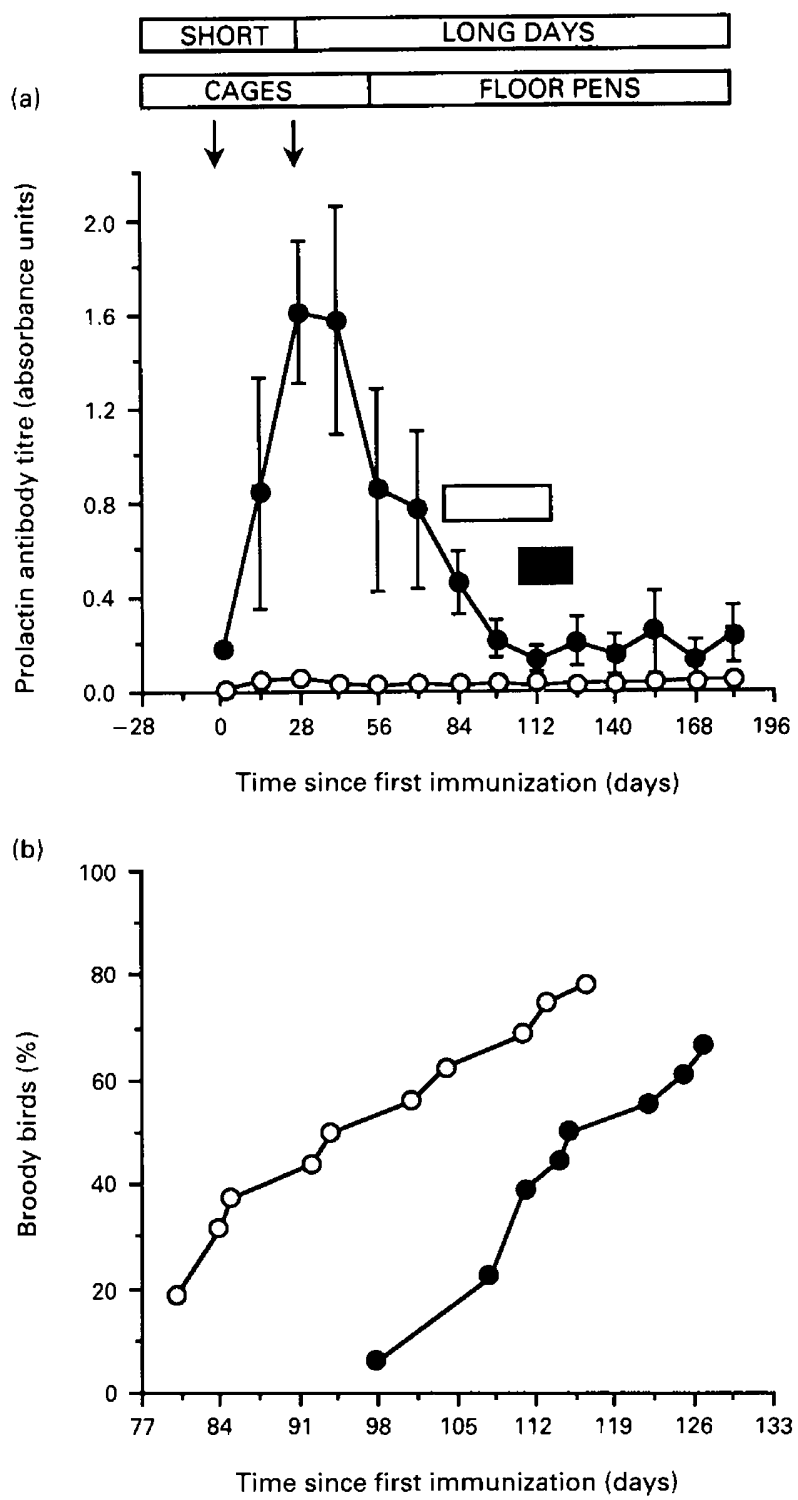

Fig. 2. The effects of active immunization of adult bantam hens with a chicken prolactin recombinant-derived fusion protein ( $\beta \mathrm{gal}_{\mathrm{S}}-$ prolactin,,$n=18$ ) or control immunogen $(O, n=16)$ on (a) the titres of chicken prolactin antibodies in the blood and onset of incubation behaviour, and (b) the development of incubation behaviour. The arrows show the times at which the birds were immunized. The periods when broodiness began are shown ( $\square$ ) for hens immunized with $\beta \mathrm{gal}_{\mathrm{S}}$-prolactin and $(\square)$ for hens immunized with the control immunogen. Values are means \pm SEM.

At the time the laying hens were transferred to pens to induce broodiness, the titres of prolactin antibodies were falling (Fig. 2a). Twelve of the 16 control hens and 12 of the 18 hens immunized with $\mathrm{Bgal}_{\mathrm{s}}$-prolactin became broody. The time required for the control birds to become broody $(36.3 \pm 12.2$ days) after transfer to the floor pens was significantly less $(P<0.001)$ than that required by the experimental hens (57.2 \pm 8.2 days). However, after the first hen in each group became broody, the rates at which broodiness developed in the control and experimental groups were similar (Fig. 2b). 
(a)

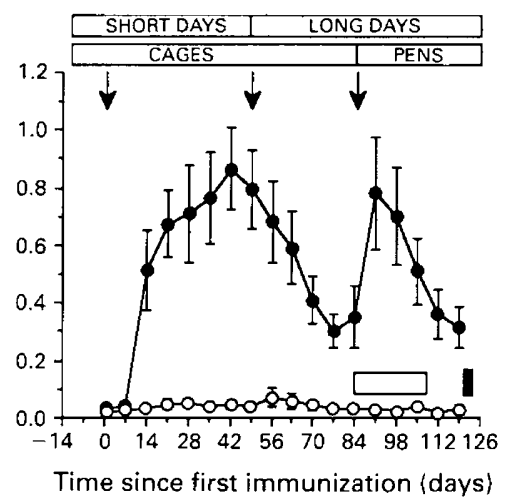

(b)
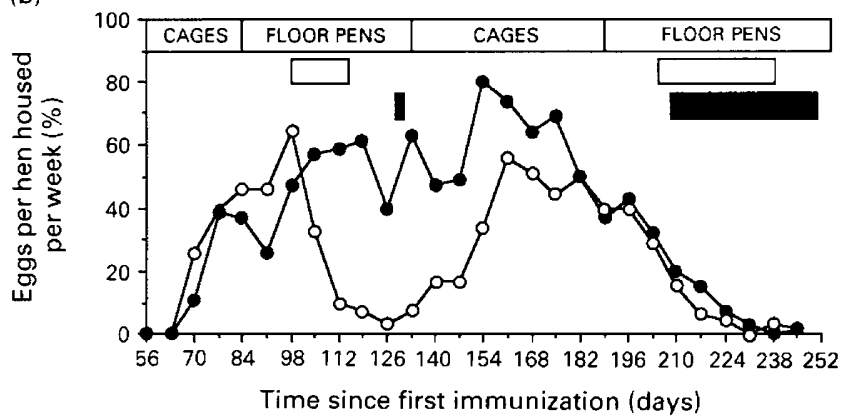

Fig. 3. The effects of active immunization of adult bantam hens with a chicken prolactin recombinant-derived fusion protein ( $\mathrm{ggal}_{\mathrm{S}}$ prolactin,,$n=10$ ) or control immunogen $(O, n=10)$ on (a) the titres of chicken prolactin antibody in the blood and onset of incubation behaviour, and (b) the rate of egg laying. All hens were returned to cages on day 133 to break broodiness and put back into pens on day 189 to induce a second round of broodiness. The arrows show the times when the birds were immunized. The periods when broodiness began are shown ( $\square$ ) for hens immunized with the control immunogen and as $(\boldsymbol{G})$ in hens immunized with $\beta_{g a l}-$ prolactin. Values are means \pm SEM.

Effect of maintaining plasma prolactin antibodies after the onset of egg laying on the induction of incubation behaviour

In Expt 2, it was confirmed that active immunization of photosensitive non-laying hens with $\mathrm{Bgal}_{\mathrm{s}}$-prolactin stimulated the production of prolactin antibodies but did not prevent the induction of egg laying after photostimulation (Fig. 3a, b). Maintenance of high titres of prolactin antibody after transfer to floor pens inhibited the induction of broodiness (Fig. 3a) and allowed egg laying to continue (Fig. 3b). During the 49 days the birds were in the floor pens, eight of ten control hens and one of ten experimental birds became broody. The experimental birds showed a significant reduction in the incidence of broodiness compared with control birds $(P<0.01$ Fisher's exact test). The one experimental bird that became broody did so after its prolactin antibody titre had decreased to the point where it was only just detectable by ELISA.

After the hens were returned to individual cages all broody birds came back into lay (Fig. 3b). When the hens were returned to floor pens to induce a second period of broodiness, seven of the nine surviving control hens and nine of the ten experimental hens became broody. The development of the second period of broodiness was associated with decreased

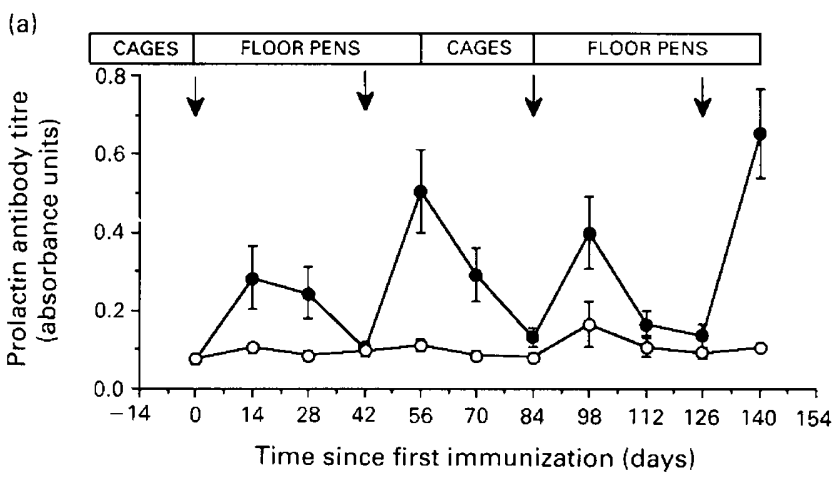

(b)

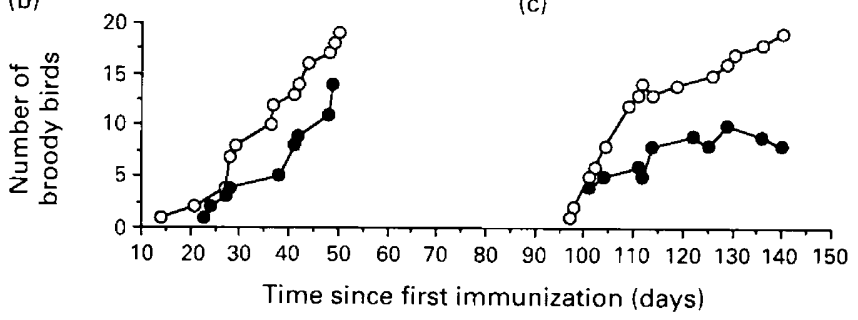

Fig. 4. The effects of active immunization of laying bantam hens (exposed to $14 \mathrm{~h}$ light:10 $\mathrm{h}$ darkness) with a chicken prolactin recombinant-derived fusion protein $\left(\beta \beta_{\mathrm{sal}}\right.$-prolactin, $\left.\bullet, n=21\right)$ or control immunogen $(O, n=21)$ on (a) the titres of chicken prolactin antibodies in the blood and the onset of incubation behaviour, and $(b, c)$ the incidence of incubation behaviour, induced on two successive occasions by transfer from cages to pens. The arrows show the times when the birds were immunized. Values are means \pm SEM.

egg production in both control and experimental groups (Fig. 3b).

Effect of immunization with $\beta g a l_{S}-$ prolactin after the onset of egg laying on the development of incubation behaviour

In Expt 3, active immunization of hens with $\mathrm{Bgal}_{\mathrm{S}}$-prolactin after the onset of egg laying on two occasions separated by 42 days stimulated the production of prolactin antibodies (Fig. 4a) but did not significantly reduce the incidence of broodiness (Fig. 4b, c). Fifty days after transfer to floor pens 19 of 21 control hens and 14 of 21 experimental hens were broody: all the experimental hens had prolactin antibodies in their blood (not significantly different from each other, Fisher's exact test). The experiment was repeated after returning the birds to cages to break broodiness (Fig. 4a). All control $(n=21)$ and experimental $(n=21)$ hens were laying when they were returned to floor pens to induce a second round of broodiness. Once again the birds were immunized with $\beta_{g a l}$-prolactin or control immunogen on two occasions separated by 42 days (Fig. $4 a$ ). Fifty-six days after transfer to floor pens for the second time, 19 of 21 control hens, and 9 of 21 experimental hens were broody ( $P<0.05$, Fisher's exact test) (Fig. 4c). During this experiment, an attempt was made to maintain prolactin antibody titres by immunizing the hens at intervals of 42 days. Antibody titres reached their highest values 14 days after each immunization and thereafter decreased to almost undetectable values after 42 days (Fig. $4 a$ ). 
(a)

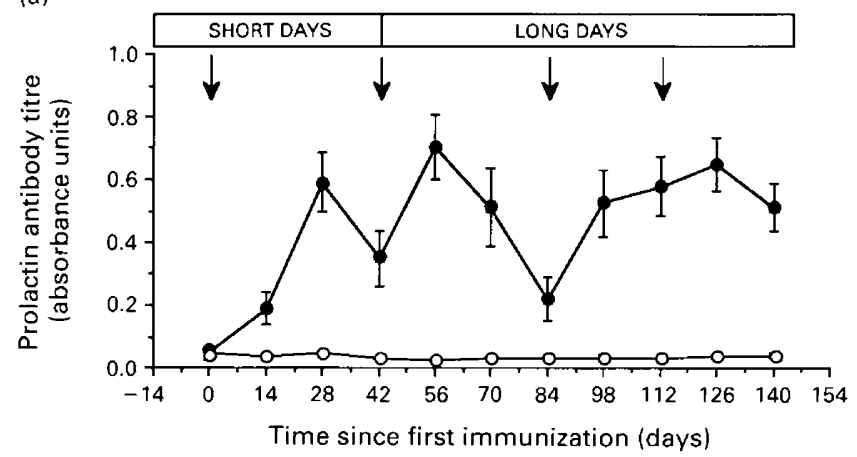

(b)

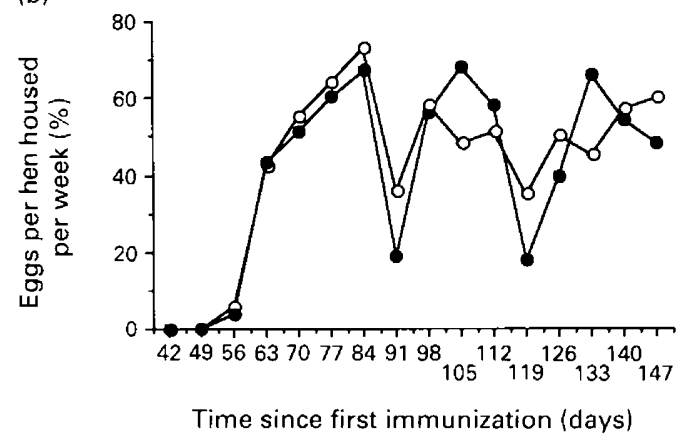

Fig. 5. The effects of active immunization of adult bantam hens with a chicken prolactin recombinant-derived fusion protein $\left(\beta \mathrm{gal}_{\mathrm{S}}-\right.$ prolactin, $n=22$ ) or control immunogen ( $\bigcirc, n=24$ ), on (a) the titre of chicken prolactin antibodies in the blood and (b) the rate of egg laying. The hens were kept in individual cages to inhibit the development of broodiness, and exposed to long days (14 h light:10 $\mathrm{h}$ darkness) to stimulate egg laying. The arrows show the times at which the birds were immunized. Values are means \pm SEM.

Effect of immunization with $\beta g a l_{s}$-prolactin before the onset of egg production on the rate of egg laying

In Expt 4 , birds immunized with $\mathrm{\beta gal}_{\mathrm{S}}$-prolactin maintained prolactin antibodies in their blood throughout the period observations were made on egg production (Fig. $5 a, b$ ). The rate of egg laying in hens caged individually to inhibit the development of broodiness and immunized with $\mathrm{Bgal}_{\mathrm{S}}-$ prolactin was similar to that in hens immunized with control immunogen (Fig. 5b). Reduction in egg laying occurred in control and experimental hens for a week after each occasion on which the birds were immunized, and therefore reflected an adverse response to Freund's incomplete adjuvant (Fig. 5b).

\section{Discussion}

The recombinant-derived chicken prolactin fusion protein proved to be an effective immunogen for the stimulation of chicken prolactin antibodies in bantam hens. It was assumed at the initiation of the study that as chicken prolactin is in essence a 'self-protein' it would not be an effective immunogen. For this reason, it was decided to attempt to make chicken prolactin immunogenic by combining it with a short amino acid sequence of bacterial $\beta$-galactosidase. This experimental approach was based on the observation that the development of a human anti-pregnancy vaccine against human chorionic gonadotrophin requires that the $\beta$ subunit be linked to a foreign protein to enhance immunogenicity (Talwar et al., 1976; Nash et al., 1980).

It was anticipated that a primary and secondary immunization separated by $4-6$ weeks would be adequate to induce and maintain prolactin antibody titres for 2 or 3 months, but this was not found to be the case. It is not known why the second immunizations in Expts 1 and 2 failed to enhance the immune response. However, in Expts 3 and 4 it became clear that immunizations were required at monthly intervals to maintain maximum titres of prolactin antibody.

Despite the failure to maintain consistently increased prolactin antibody titres, the presence of prolactin antibodies delayed the onset of incubation behaviour in Expts 1,2 and 3. The delay in the onset of incubation behaviour was most pronounced in Expt 2 in which the period during which the behaviour was predicted to develop coincided with maximal titres of prolactin antibodies. The delay in the onset of incubation behaviour was not so pronounced in Expt 1, probably because titres of prolactin antibodies in the experimental hens were approaching baseline values at the time the control birds were becoming broody. However, the onset of incubation behaviour was still significantly delayed. This observation may be of significance because it implies that the induction of broodiness under normal conditions may depend on prolonged exposure to the moderately high concentrations of prolactin found in laying hens (Talbot et al., 1991).

It has been proposed that prolonged exposure to these concentrations of plasma prolactin decrease a CNS threshold to environmental stimuli that encourage incubation behaviour (Sharp, 1989). Some of the stimuli, present in these studies, included the availability of a nest site and the presence of a clutch of eggs. This view receives support from Expt 3 in which hens received primary immunization against prolactin after the onset of egg laying. The presence of prolactin antibody failed to disrupt the development of incubation behaviour to the same extent as that observed in hens in which the primary immunization was given before the onset of laying. However, after these hens had been repeatedly immunized against prolactin for 3 months, the development of a second round of broodiness was inhibited. This observation further strengthens the view that the development of broodiness depends on prior prolonged exposure to moderately increased concentrations of plasma prolactin.

These observations extend passive immunization studies in broody bantam hens, using anti-vasoactive intestinal polypeptide serum, which support the view that increased plasma prolactin plays a role in the maintenance of incubation behaviour (Sharp et al., 1989). In addition to being involved in the maintenance of incubation behaviour, this study provides direct evidence that the increase in prolactin secretion at the onset of incubation facilitates the initiation of the behaviour.

Experiment 2 established that the failure of hens actively immunized against prolactin to become broody was not because they were genetically incapable of doing so. This could be tested because the bantams are from a flock with mixed ancestry, including White Leghorn stock that does not show broody behaviour (Saiti and Inoue, 1979). All the hens that failed to become broody when they had high titres of prolactin 
antibody became broody after a second round of broodiness was induced and when titres of prolactin antibody would have been low.

Prolactin acts directly on the avian ovary to inhibit LH-induced oestrogen production by small follicles (Zadworny et al., 1989) and on the neuroendocrine system to inhibit LH secretion (Buntin et al., 1988; Sharp et al., 1988; El Halawani et al., 1991). It is therefore possible that active immunization against prolactin may affect photoinduced ovarian growth and subsequent persistency of egg laying. These questions were addressed in Expts 2 and 4 . In both these experiments, the presence of antibodies to prolactin in the blood during photostimulation did not affect the rate at which hens came into egg production. It therefore appears that immunoneutralization of plasma prolactin does not modify the photoperiodic reflex.

In Expt 4, broodiness was discouraged by keeping the hens caged individually. In this situation, it was possible to determine the rate of egg laying in hens immunized with $\mathrm{Bgal}_{\mathrm{S}^{-}}$ prolactin in the absence of broodiness. The rate of egg laying in hens immunized with the control immunogen was similar to that in hens immunized with $\beta g \mathrm{gal}_{\mathrm{S}}$-prolactin to induce prolactin antibody production. It is therefore concluded that the moderately increased concentration of prolactin in laying hens (Talbot et al., 1991) does not play an essential role in maintaining ovarian folliculogenesis.

This work was supported by an Open Contract from the Ministry of Agriculture, Food and Fisheries (CSA 1361), UK.

\section{References}

Buntin JD, Lea RW and Figge GR (1988) Reductions in plasma LH concentration and testicular weight in ring doves following intracranial injection of prolactin or growth hormone Journal of Endocrinology 118 33-40

El Halawani ME, Silsby JL, Behnke EJ and Fehrer SC (1986) Hormonal induction of incubation in ovariectomized female turkeys (Meleagris gallopavo) Biology of Reproduction 35 59-67

El Halawani ME, Fehrer S, Hargis BM and Porter TE (1988) Incubation behaviour in the domestic turkey: physiological correlates $C R C$ Critical Reviews in Pouitry Biology 1 285-314

El Halawani ME, Silsby JL, Youngren OM and Phillips RE (1991) Exogenous prolactin delays photoinduced sexual maturity and suppresses ovariectomy induced luteinizing hormone secretion in the turkey (Meleagris gallopavo) Biology of Reproduction 44 420-424

Feinberg AP and Vogelstein B (1984) A technique for radiolabelling DNA restriction fragments to high specific activity Analytical Biochemistry 132 6-13

Hanahan D (1983) Studies on transformation of Escherichia coli with plasmids Joumal of Molecular Biology 166 557-580

Hanks MC, Talbot RT and Sang HM (1989) Expression of biologically active recombinant-derived chicken prolactin in Escherichia coli journal of Molecular Endocrinology 3 15-21
Lea RW (1987) Prolactin and avian incubation: a comparison between Galliformes and Columbiformes Sitta 1 117-141

Lea RW, Dods ASM, Sharp PJ and Chadwick A (1981) The possible role of prolactin in the regulation of nesting behaviour and the secretion of luteinizing hormone in broody bantams Journal of Endocrinology 91 89-97

Messing J, Gonenborn B, Müller-Hill B and Hofschneider PH (1977) Filamentous coliphage M13 as a cloning vehicle: Insertion of a HindII fragment of the lac regulatory region in M13 replicative form in vitro Proceedings of the National Academy of Sciences USA 74 3642-3646

Nash H, Talwar GP, Segal S, Luutkainen T, Johnsson EDB, Vasquez J, Coutinho E and Sundaran K (1980) Observations on the antigenicity and clinical effects of a candidate antipregnancy vaccine: $\beta$-subunit of human chorionic gonadotropin linked to tetanus toxoid Fertility and Sterility 34 328-335

Opel H and Proudman JA (1980) Failure of mammalian prolactin to induce incubation behavior in chickens and turkeys Poultry Science 59 2550-2558

Saiti $Y$ and Inoue $Y$ (1979) Body growth, egg production, broodiness, age at first egg and egg size in Red Jungle Fowls, and an attempt at their genetic analyses by the reciprocal crossing with White Leghorns Japanese Poultry Science 16 121-125

Sambrook J, Fristch EF and Maniatis T (1989) In Molecular Cloning: a Laboratory Manual. Cold Spring Harbor Laboratory Press, New York

Sharp PJ (1989) Physiology of egg production. In Recent Advances in Turkey Science pp 31-54 Eds C Nixey and TC Grey. Butterworths, Sevenoaks

Sharp PJ, Scanes CG, Williams JB, Harvey S and Chadwick A (1979) Variations in the concentrations of prolactin, luteinizing hormone, growth hormone and progesterone in the plasma of broody bantams (Gallus domesticus) Journal of Endocrinology 80 51-57

Sharp PJ, Macnamee MC, Sterling RJ, Lea RW and Pedersen HC (1988) Relationships between prolactin, $\mathrm{LH}$ and broody behaviour in bantam hens Journal of Endocrinology 118 279-286

Sharp PJ, Sterling RJ, Talbot RT and Huskisson NS (1989) The role of hypothalamic vasoactive intestinal polypeptide in the maintenance of prolactin secretion in incubating bantam hens: observations using passive immunization, radioimmunoassay and immunohistochemistry Journal of Endocrinology 122 5-13

Talbot RT, Hanks MC, Sterling RJ, Sang HM and Sharp PJ (1991) Pituitary prolactin messenger ribonucleic acid levels in incubating and laying hens: effects of manipulating plasma levels of vasoactive intestinal polypeptide Endocrinology 129 496-502

Talmar GP, Dubey SK, Salahuddin M, Das C, Hingorani V and Kumar S (1976) Antibody response to $\mathrm{Pr}-\beta \mathrm{hCG}$-TT vaccine in human subjects Contraception $13237-245$

Towbin H, Staehelin T and Gordon J (1979) Electrophoretic transfer of proteins from polyacrylamide gels to nitrocellulose sheets: procedure and some applications Proceedings of the National Academy of Sciences USA 764350 4354

Yanisch-Perron C, Vieira J and Messing J (1985) Improved M13 phage cloning vectors and host strains: Nucleotide sequences of the M13mp18 and pUC19 vectors Gene 33 102-119

Youngren OM, El Halawani ME, Silsby JL and Phillips RE (1991) Intracranial prolactin perfusion induces incubation behaviour in turkey hens Biology of Reproduction 44 425-431

Zadworny D, Shimada K, Ishida H and Sato K (1989) Gonadotropin-stimulated estradiol production in small ovarian follicles of the hen is suppressed by physiological concentrations of prolactin in vitro General and Comparative Endocrinology 74 468-473 